\title{
Electronic Citizen Relationship Management (e-CiRM) Modeling towards Serang as a Smart City
}

\author{
Vidila Rosalina \\ Faculty of Information Technology \\ Universitas Serang Raya \\ Jl. Raya Serang-Cilegon Km.5 \\ Banten Indonesia
}

\author{
Tb Ai Munandar \\ Faculty of Information Technology \\ Universitas Serang Raya \\ Jl. Raya Serang-Cilegon Km.5 \\ Banten Indonesia
}

\author{
Achmad Nizar Hidayanto \\ Faculty of Computer Science \\ Universitas Indonesia \\ Depok Indonesia
}

\begin{abstract}
Following the rapid advancement of Information Communication Technology (ICT), the lifestyle of citizens has also changed. Various applications are present at your fingertips through your device. In turn, the digital era also affects the relationship between the government and citizens. The government is required to be able to keep up with the times. The use of information technology for mobile government is something that cannot be negotiated. The use of ICT in government is a necessity, one of which is for interactive communication with citizens. Adaptation of the bureaucracy to technology, mobile apps for urban public services is one indicator of an ongoing evolution, namely smart government. With the spirit of a smart city, Citizen Relationship Management (C iRM) is expected to accommodate several changes related to bureaucratic work patterns in following up on citizen complaint reports. This study tries to create an Electronic Citizen Relationship Management (e-CiRM) model for the city of Serang. The existing model in e-CiRM will assist the government in implementing good relationship management with citizens so as to increase citizen satisfaction with the city government of Serang. System modeling uses the Zachman framework (Zachman Frameworks) in order to obtain a complete and comprehensive picture. The results of the model developed in this study are expected to increase citizen satisfaction with the city government of Serang in an effort to realize the city of Serang as a smart city.
\end{abstract}

\section{Keywords}

e-CiRM, Citizen, Serang, Smartcity, Zachman Frameworks.

\section{INTRODUCTION}

Following the development of ICT, the lifestyle of the people of Serang city has also changed, various services are present in the form of handheld applications. Starting from transactions, learning to just social networking. This phenomenon cannot be separated from the easier and cheaper internet access. According to research on the social media management platform HootSuite and social marketing agency We Are Social entitled "Global Digital Reports 2020", nearly 64 percent of Indonesia's population is connected to the internet network, reaching 175.4 million users. But in fact, there are far more mobile internet users, almost 2 times that. Currently, it is recorded that Indonesians who use internet connections on mobile devices, such as smartphones or tablets, reach 338.2 million users [1]. The combination of these two things has formed an always on society. In turn, the digital era also affects the relationship between the government and its citizens. The use of mobile government is something that cannot be negotiated. Mobile apps for urban public services are an indicator of an ongoing evolution, namely "ubiquitous government" or "smart government" [2]. It takes a more progressive response from the government to adjust to the changes taking place in the digital era. The bureaucratic structure must be improved to accommodate new technology and its utilization [3].

With the spirit of a smart city, e-CiRM is expected to accommodate several changes related to the work patterns of the bureaucracy in following up on reports. One of them is by creating a coordination feature from urban village heads to Regional Government Agencies, then disposition features from urban village heads or Regional Government Agencies to related officers. The mayor can directly monitor the performance of his subordinates as well as monitor the satisfaction level of the citizens. Of course, this change is not easy to accept. During the process of preparing a legal basis for using the e-CiRM application, the urban village head can forward the report to the Regional Government Agencies. This idea can be accepted after it is understood that the logic used is functional rather than structural. This change inevitably forces Regional Government Agencies to be more aware of e-CiRM and the various problems it reports. In the past, the focus was on the urban village, which incidentally had very limited authority and resources. E-CiRM initiated a new method to ensure that all citizen reports and complaints can be properly monitored. This is important in maintaining citizen engagement.

The results of the research show that the use of technology has changed the interaction pattern in government communication, from being unidirectional to two-way or interactive. This finding is at the same time the antithesis of the opinion of Pasquier (2012) which states that the core function of government communication is to convey information and public policies from the government to citizens. With this awareness, Electronic Citizen Relationship Management (e-CiRM) will be a very useful application in ensuring the best service for citizens [4].

Research on e-CiRM modeling was carried out based on the Serang Raya University Research Master Plan as a bridge in order to solve problems that occur related to government services to the community, especially in the Banten region. ECiRM modeling in an effort to build Serang towards smartcity is one of the sub-fields of smart governance for Social and Public Services including Electronic-Based City Services (emunicipalty / e-government). The research developed in the field of smart governance is indeed directed at assisting the government in improving services to the community so that it can be maximized. The direction of research in this field is not only developing applications based on information technology, but also directed to be able to contribute to the 
development of the master plan for the development of the smart city concept in the city of Serang, Banten.

Based on the research roadmap, studies on ICT implementation policies in supporting government performance are the focus of research. The research began in 2015 by conducting research related to the need for health service reports received by the public at each existing health facility. The research output was in the form of the Smart Online Reporting Complain Healthy Care (SOCHARE) application and the results were presented in a national seminar. The next research was conducted in 2016, which is related to information services and accident complaints for the Serang City Police. The research output is in the form of the SORAC AREAS application (Smart Online Reporting Acident Prone Areas) and the results have been presented in a national seminar. In the same year (2016) research related to the evaluation of public services in Pandeglang was carried out with an informative technology approach. The research output was in the form of Prototype Smart Online Reporting Agencies Service (SORAS) and was published through the dissemination of research results at the Pandeglang Regency level.

While a review of research related to E-CRM, namely, Alhadar (2011) produced E-CRM in Municipal Waterworks in Jakarta using System Dynamic Modeling [5]. Alkhouri (2012) produced a framework for the E-CRM model in governance, the framework is designed in three phases: preimplementation, implementation, and post-implementation [6]. Ghozali (2014) produced an E-CRM model framework at the Marine and Fisheries Service, making an E-CRM model starting from strategic planning, service development, making information systems architecture [7]. Rosalina V (2018) produces e-CRM for MSMEs in Banten [8-11].

The results of literature studies of previous studies on CRM implementation will certainly be very different between MSMEs, service companies [12], and large companies [1316]. This is also what drives this e-CiRM research.

Several previous e-CiRM studies have produced an onlinebased system design with the smartcity concept in which the community becomes a partner for the government in implementing development. Meanwhile, this research attempts to model e-CiRM in the local government of the city of Serang by using the Zachman Framework in order to obtain a complete and comprehensive picture of the e-CiRM model.

\section{RESEARCH METHOD}

Preliminary studies have been carried out to prepare for this research, namely by preparing several supporting theories and previous research on Smartcity, Electronic Citizen Relationship Management (e-CiRM), Zachman Framework.

Smartcity was first initiated by IBM in America and then adopted by various countries to regulate and organize urban life to improve the quality of life for its residents. Some of them are the City of Copenhagen in Denmark with a main focus on optimizing one of the six indicators of smart city, namely the environment, South Korea, and Seoul by focusing on public services in the field of information technology. So it is not surprising that South Korea is known for the fastest internet network access in the world [17].

In the City of Berlin, Germany, the smart city framework was developed to support the development of sustainable urban communities with an emphasis on administrative services, housing, economy, mobility, infrastructure and public security [18]. In the city of Parramatta in Australia, the smartcity framework is used to promote local government conception with a focus on better services for local communities, increasing efficiency and services, stimulating community economic activity so that a better level of sustainable development is obtained [19]. The city of Vienna in Austria has also developed a smart city framework with the motto "Vienna has 1.7 milliom brains. Let's use them". Through this motto, a smart city framework is developed by prioritizing the concept of intelligence, creativity and analysis of city residents to support the creation of the expected smart city [20].

Several cities in Indonesia that are also implementing smartcity include Jakarta, Bandung, Yogyakarta, Surabaya and Makassar. At the district level, the Banyuasin Regency Government has successfully developed smartcity, which has successfully entered the top 25 national level smartcity and was selected as a pilot project in the development of a smart city. In this case, the smart city concept developed by Banyuasin Regency has succeeded in improving public services, adequate infrastructure, proper health and education, and improving the people's economy (http://banyuasinkab.go.id). Smartcity was also developed in Balikpapan Regency by identifying the environmental sector, public services and transportation supported by adequate human resources, infrastructure and local government policies. Several other cities / regencies that have implemented the smart city concept include Batang Regency, Badung Regency, Bandung Municipality and many more cities in Kalimantan, Sulawesi and Sumatra.

In essence, CRM is the basic concept for attracting new customers, getting to know them well, providing them with exceptional service, and anticipating their wants and needs and keeping existing customers feeling valued and needed by the company. When companies do these things well, increases in revenue and profits tend to follow. The implementation of Electronic Citizen Relationship Management in an effort to realize the city of Serang as a smart city in this research proposal will adopt the existing Customer Relationship Management (CRM) to suit the needs where citizens will be seen as customers (customers) so that complaints will be cnsidered and their satisfaction as citizens will be measured.

According to Melissa A Cook (1996), John A Zachman in the late '80s introduced a framework to assist management in implementing two main things. The first thing is to separate the main components in information systems to facilitate management in planning and development. While the second thing is how to build a strategic plan from the most global level and conceptual to the technical implementation. In principle Zachman divided the information system into three major components, namely: Data, Process, and Technology which in its development into six main entities. A practitioner named John Zachman in the late '80s analyzed this and gave one of his solutions that is still relevant today to be used. To commemorate his name, this framework is the Zachman Framework. Zachman Framework is a $6 \times 6$ matrix that represents the intersection of two classification schemes two-dimensional system architecture [21]. 


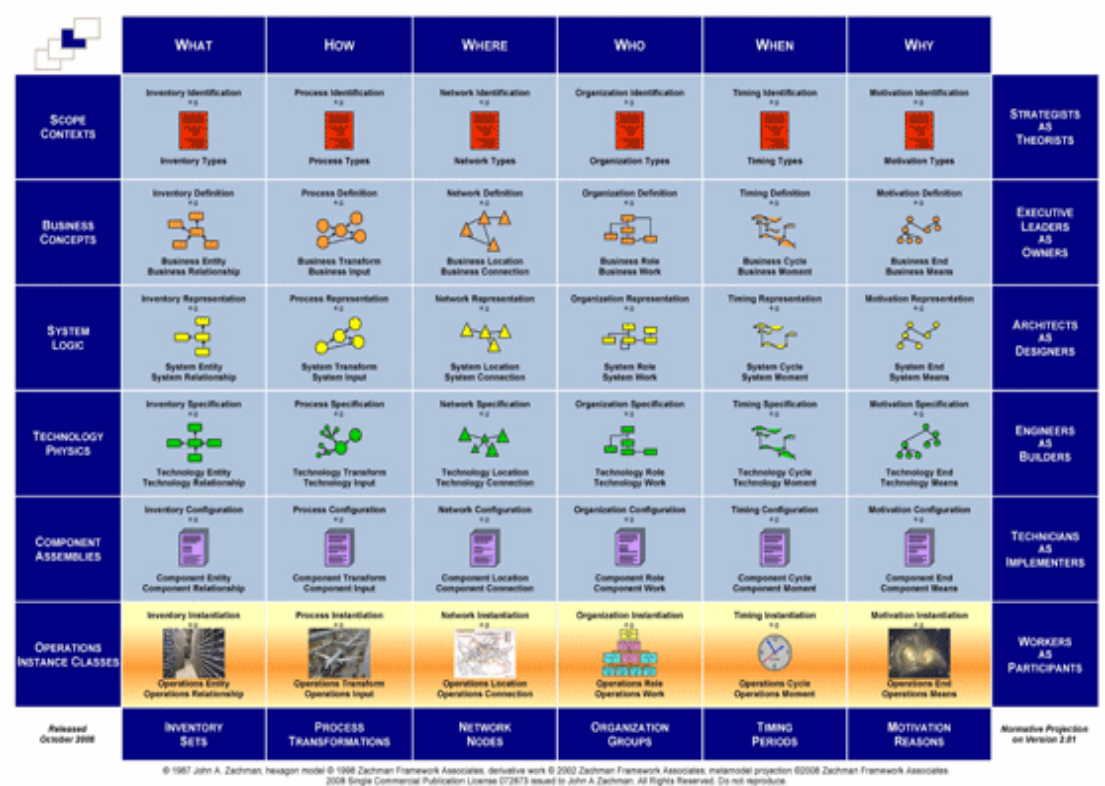

Figure 1: Zachman Framework

(http://zachmaninternational.com/index.php/home-article/13)

\section{The columns in the Zachman Framework include:}

1. Who: representing poeple's relationship in the organization. The design of the organization of the company must relate to the allocation of work and the authority of structure and responsibility.

2. When: representing the time or event relationship that creates performance criteria and quantitative levels for company resources. This is useful for designing schedules, processing architectures, control architectures, and timing devices.

3. Why: describing the company's motivations. It shows goals and objectives, business plans, knowledge architecture, and knowledge design.

4. What: describing the entities involved in each company perspective. For example including business objects, system data, relational tables and definitions.

5. How: showing the functions in each perspective. For example including business processes, software application functions, computer hardware functions, and control loop languages.

6. Where: showing the locations and interconnections within the company. These include major geographical locations, separate sections within the logistics network, allocation of system nodes or even memory addressing in the system [22].

\begin{tabular}{|c|c|c|c|c|c|c|}
\hline & Why & How & What & Who & Where & When \\
\hline Contextual & $\begin{array}{l}\text { Goal } \\
\text { List }\end{array}$ & $\begin{array}{l}\text { Process } \\
\text { List }\end{array}$ & $\begin{array}{l}\text { Material } \\
\text { List }\end{array}$ & $\mid \begin{array}{c}\text { Organizationd } \\
\text { Unit \& } \\
\text { Role List }\end{array}$ & $\begin{array}{c}\text { Geographica } \\
\text { Locations } \\
\text { List }\end{array}$ & $\begin{array}{l}\text { Event } \\
\text { List }\end{array}$ \\
\hline Conceptual & $\begin{array}{c}\text { Goal } \\
\text { Relationship }\end{array}$ & $\begin{array}{l}\text { Process } \\
\text { Model }\end{array}$ & $\begin{array}{c}\text { Entity } \\
\text { Relationship } \\
\text { Model }\end{array}$ & $\mid \begin{array}{c}\text { Organizationd } \\
\text { Unit \& Role } \\
\text { Rel. Model }\end{array}$ & $\begin{array}{l}\text { Locations } \\
\text { Model }\end{array}$ & $\begin{array}{l}\text { Event } \\
\text { Model }\end{array}$ \\
\hline Logical & $\begin{array}{c}\text { Rules } \\
\text { Diagram }\end{array}$ & $\begin{array}{l}\text { Process } \\
\text { Diagram }\end{array}$ & $\begin{array}{c}\text { Data Model } \\
\text { Diagram }\end{array}$ & \begin{tabular}{|c} 
Role \\
relationship \\
Diagram
\end{tabular} & $\begin{array}{l}\text { Locations } \\
\text { Diagram }\end{array}$ & $\begin{array}{l}\text { Event } \\
\text { Diagram }\end{array}$ \\
\hline Physical & $\begin{array}{c}\text { Rules } \\
\text { Specification }\end{array}$ & $\begin{array}{c}\text { Process } \\
\text { Function } \\
\text { Specification }\end{array}$ & $\begin{array}{c}\text { Data } \\
\text { Entity } \\
\text { Specification }\end{array}$ & $\left|\begin{array}{c}\text { Role } \\
\text { Specification }\end{array}\right|$ & $\begin{array}{c}\text { Location } \\
\text { Specification }\end{array}$ & $\begin{array}{l}\text { Event } \\
\text { Specification }\end{array}$ \\
\hline Detailed & $\begin{array}{l}\text { Rules } \\
\text { Details }\end{array}$ & $\begin{array}{l}\text { Process } \\
\text { Detals }\end{array}$ & $\begin{array}{l}\text { Data } \\
\text { Details }\end{array}$ & $\begin{array}{c}\text { Role } \\
\text { Details }\end{array}$ & $\begin{array}{c}\text { Location } \\
\text { details }\end{array}$ & $\begin{array}{l}\text { Event } \\
\text { Details }\end{array}$ \\
\hline
\end{tabular}

Figure 2: Zachman Framework Classification Matrix (Model of Cells Zachman Framework) (http://www.zachmanframeworkassociates.com/index.php/the-zachman-framework)

The Zachman Framework does not provide a specific model and architecture with which to provide a complete description. Zachman Framework users are free to choose the tools that will be used to apply the model to be created. Zachman framework is also free to use on any object, not only for companies. The stages of the research methodology carried out in the e-CiRM modeling research in Serang Banten are as follows: 


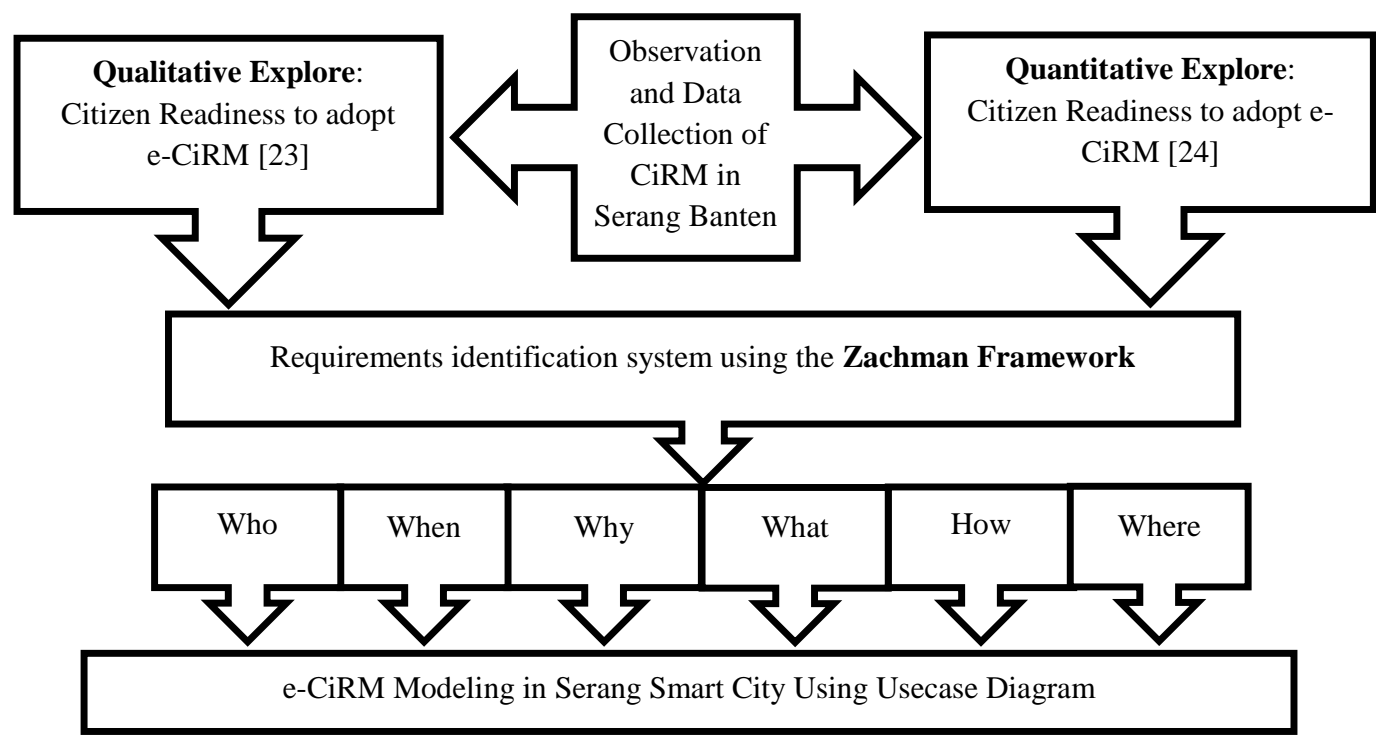

Figure 3. Research Metodology

\section{ANALYSIS AND RESULT}

Analysis of the needs of the Electronic Citizen Relationship Management (e-CiRM) system is based on the readiness of citizens in Serang Banten using a qualitative approach and a quantitative approach. E-CiRM modeling will assist the government in implementing CRM so that it can foster good relations with citizens and of course provide the best and satisfying service to citizens.

System modeling using the Zachman framework. The following is a representation of e-CiRM based on 6 matrix columns (who, how, what, why, when, where) in Zachman frameworks as shown in table 1 below:

Table 1. Representative The Columns in Zachman Frameworks to e_CiRM Serang Smart City

\begin{tabular}{|c|c|c|c|}
\hline $\begin{array}{l}\text { The Columns } \\
\text { in Zachman } \\
\text { Frameworks }\end{array}$ & $\begin{array}{l}\text { Representative in e-CiRM } \\
\text { Model }\end{array}$ & $\begin{array}{l}\text { Representative in } \\
\text { Usecase }\end{array}$ & Description \\
\hline WHO & $\begin{array}{l}\text { Represents the relationship of the } \\
\text { people in government. The design } \\
\text { of e-CiRM should relate to the } \\
\text { allocation of work and structure } \\
\text { authority and responsibilities. }\end{array}$ & Actor & $\begin{array}{l}\text { 1. Citizen } \\
\text { 2. Mayor } \\
\text { 3. Regional Government Agencies } \\
\text { 4. Urban Village Head } \\
\text { 5. CiRM Admin } \\
\text { 6. Regional Government Unit Officer } \\
\text { 7. Urban Village Officer }\end{array}$ \\
\hline WHEN & $\begin{array}{l}\text { Represents the relationship of } \\
\text { events that create performance } \\
\text { criteria and quantitative levels for } \\
\text { governance resources. This is } \\
\text { useful for designing processes and } \\
\text { relationships between processes in } \\
\text { e-CiRM. }\end{array}$ & $\begin{array}{l}\text { Association } \\
<<\text { include }>>\end{array}$ & $\begin{array}{l}\text { The relationship between human resources and } \\
\text { the process and the relationship between the } \\
\text { process itself can be seen in the symbol } \\
\text { association and include in Figure } 4\end{array}$ \\
\hline WHY & $\begin{array}{l}\text { Describe the government } \\
\text { motivation to realize Serang as } \\
\text { smart city. This demonstrates the } \\
\text { basic objectives of e-CiRM. }\end{array}$ & Objectives & $\begin{array}{l}\text { Creating good relations between the } \\
\text { government and citizens and creating citizen } \\
\text { satisfaction. }\end{array}$ \\
\hline WHAT & $\begin{array}{l}\text { Describes the entities involved in } \\
\text { each perspective of government. } \\
\text { Examples include government } \\
\text { service objects, system data, } \\
\text { relational tables, and definitions. }\end{array}$ & Usecase Definitions & $\begin{array}{l}\text { 1. Register } \\
\text { 2. Login } \\
\text { 3. Make a Complaint. } \\
\text { 4. See Complaint Response } \\
\text { 5. Track Follow Up } \\
\text { 6. Rate Citizen Satisfaction } \\
\text { 7. Coordinations } \\
\end{array}$ \\
\hline
\end{tabular}




\begin{tabular}{|c|c|c|c|}
\hline & & & $\begin{array}{l}\text { 8. Disposition } \\
\text { 9. Central Government Report } \\
\text { 10. Performance Monitoring } \\
\text { 11. Citizen Satisfaction Monitoring }\end{array}$ \\
\hline HOW & $\begin{array}{l}\text { Show functions in every } \\
\text { perspective. For example the } \\
\text { function of the e-CiRM software } \\
\text { application. }\end{array}$ & $\begin{array}{l}\text { Usecase } \\
\text { Descriptions }\end{array}$ & $\begin{array}{l}\text { Citizens register first to make a complaint to } \\
\text { see the response to the complaint and the } \\
\text { follow up track. Citizens can also provide } \\
\text { citizen satisfaction rates. The urban village } \\
\text { head coordinates with regional government } \\
\text { agencies regarding the handling of citizen } \\
\text { complaints, which is the authority of the } \\
\text { agency. The urban village head then carries out } \\
\text { a delegation disposition to the urban village } \\
\text { officer regarding complaint handling which is } \\
\text { the authority of the urban village. CiRM Admin } \\
\text { is tasked with inputting the follow-up } \\
\text { complaint track, inputting performance } \\
\text { monitoring, making reports to the central } \\
\text { government. The Mayor monitors the } \\
\text { performance and monitors the satisfaction level } \\
\text { of citizens. }\end{array}$ \\
\hline WHERE & $\begin{array}{l}\text { Shows the interconnection in } \\
\text { government and government } \\
\text { connections with citizens. }\end{array}$ & - & $\begin{array}{l}\text { The model is designed with the understanding } \\
\text { that the software is built based on android } \\
\text { connected to the Internet. }\end{array}$ \\
\hline
\end{tabular}

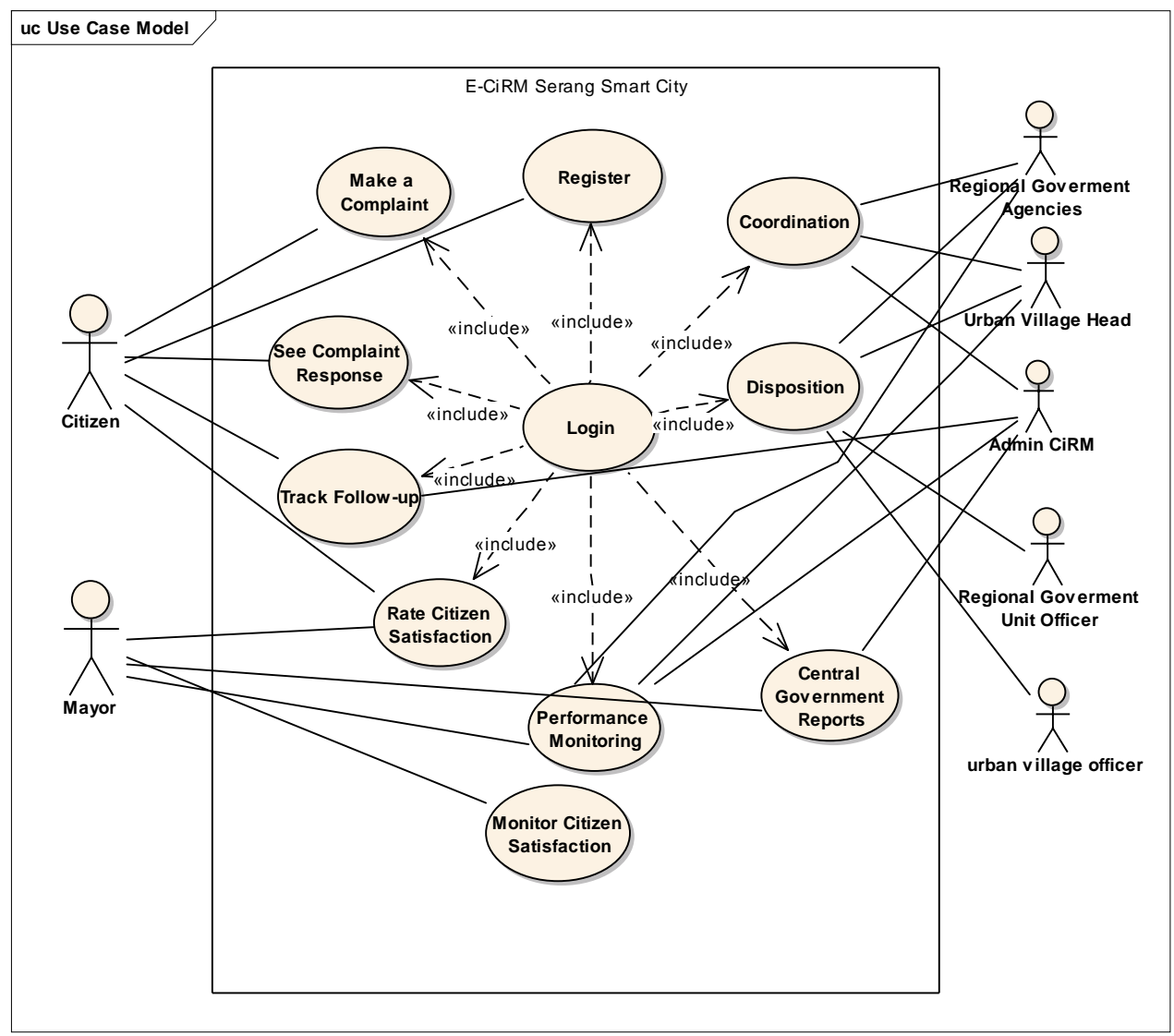

Figure 4: e-CiRM Modeling Serang Smart: Usecase Diagram

\section{CONCLUSION}

From the discussion of the analysis and results described above, it can be concluded that:

1. Identification of e-CiRM needs in the city of Serang
Banten with a qualitative and qualitative exploration approach to see the readiness of citizens using Zachman Frameworks which includes a six-column matrix (who, when, why, how, what, where) can produce an appropriate e-CiRM model, complete 
and thorough.

2. e-CiRM modeling in Serang resulted in 11 usecases and 7 actors involved to be implemented into software that could support Serang towards a smart city.

\section{ACKNOWLEDGEMENT}

This articles is part of Higher Education Collaborative Research between the University of Serang Raya and the University of Indonesia funded by the Ministry of Research, Technology and Higher Education.

\section{REFERENCES}

[1] HootSuite \& We Are Social (2020), Global Digital Reports 2020, https://datareportal.com/reports/digital2020-indonesia.

[2] L Carter, F Bélanger (2005). The utilization of e-government services: citizen trust, innovation and acceptance factors. Information systems journal 15 (1), $5-25$

[3] Stephen Goldsmith, Susan Crawford (2014). The Responsive City: Engaging Communities Through DataSmart Governance. ISBN: 978-1-118-91090-0 Aug 2014, Jossey-Bass.

[4] Shendy Adam (2017), CRM, Aplikasi Birokrat Ibu Kota "Zaman Now". https://www.kompasiana.com/shendyadam.

[5] Alhadar Nurul Safina (2011), Analisis Dan Perancangan Electronic Customer Relationship Managemnet (ECRM) Pada PT. Pam Lyonnaise Jaya, UIN Syarif Hidayatullah, Jakarta.

[6] Alkhouri, (2012). Customer Relationship Management: Proposed Framework from a Government Perspective. Journal of Management and Strategy ISSN 1923-3965 E-ISSN 1923-3973 Vol. 3, No. 4; 2012.

[7] Ghozali, (2014), Pembuatan Model Customer Relationship Management (CRM) E-Government Di Dinas Kelautan Dan Perikanan D.I.Y. JSTI ISSN 23385197 Volume 2 No 1.

[8] Rosalina V, (2017). Electronic Customer Relationship Management (E-CRM) Modeling on Micro, Small \& Medium Enterprises (MSMEs) Banten. International Journal of Computer Applications - IJCA (0975 - 8887) Vol.176, October 2017.

[9] Rosalina, Vidila., Hamdan, (2018), Electronic Customer Relationship Management (E-CRM) Modeling As Efforts to Increase Customer Retention of Micro Small and Medium Enterprises (MSMEs) in Banten. International Conference On Computer Science Engineering and Technology : ICComSET 2018, Tasikmalaya, 27-28 November 2018.

[10] Rosalina, Vidila., Hamdan, Saefudin, (2019). Mobile Customer Relationship Management (m-CRM) Application Development in MSMEs Indonesia, Journal of Physic: Conference Series Volume 1179, 2019, Published under licence by IOP Publishing Ltd.

[11] Rosalina, Vidila, Hamdan, Triayudi A..(2019), Electronic Customer Relationship Management (E-CRM)
Application as Efforts to Increase Customer Retention of Micro Small and Medium Enterprises (MSMEs) in Banten Indonesia, International Journal of Computer Applications - IJCA Volume 182, January 2019, ISSN 0975 - 8887, New York

[12] Rosalina, Vidila. (2011), Pemodelan CRM pada Perusahaan Tour and Travel Agent, Jurnal PROTEKSI ISSN 2088-8546, Volume 1, No 1, 1 Agustus 2011.

[13] Rosalina, Vidila. (2013), Pemodelan CRM Pada Perusahaan Petrokimia menggunakan Zachman Framework, Jurnal ELECTRANS ISSN 1412-3762, Volume 12 No 2 (September 2013).

[14] Rosalina V (2013), Zachman Framework for Modelling CRM in PT.Lottechem, Tbk. International Journal of Engineering Associates (IJEA) ISSN 2320-0804 Volume 2 Issue 7 (November 2013).

[15] Rosalina, Vidila., Natsir, M. (2014), Rancang Bangun Customer Relationship Manajemen (CRM) pada Perusahaan Petrokimia Menggunakan Object Oriented Analisys and Design (OOAD), Prosiding Seminar Nasional Penelitian dan PKM (SNaPP) 2014: Sains, Teknologi dan Ilmu Kesehatan, Vol.4 no.1 th 2014 ISSN 2089-3582.

[16] Rosalina, Vidila. (2015), Pengujian Sistem Customer Relationship Management (CRM) Pada Perusahaan Petrokimia Menggunakan ISO/IEC 9126, JSII (Jurnal Sistem Informasi), Vol 2 Agustus 2015 ISSN 2406-7768.

[17] Plimbi Editor (2014), Smart City, Konsep Kota Cerdas Sebagai Alternatif Penyelesaian Masalah Perkotaan di Indonesia. http://www.plimbi.com/news/158601/smartcity-konsep-kota-cerdas

[18] Senate UDE, 2015, Smart City Strategy Berlin, Senate Department for Urban Development and the Environment.

[19] Parramatta City Council, 2015, SMART CITY MASTERPLAN, Parramatta City Council and Meld Strategies, Australia

[20] Vienna City Administration, 2014, Smart City Wien: Framework Strategy, Vienna City Council

[21] Cook, Melissa A. 1996, Building Enterprise Information Architectures, Prentice Hall

[22] Zachman, J.A., 2012, John Zachman's Concise Definition of the Enterprise Framework, http://www.zachman.com/aboutthe-zachman-framework.

[23] Rosalina V., Munandar Ai, Hidayanto A. N., Santoso H. B., " Citizen Readiness for Adopting Electronic Citizen Relationship Management (e-CiRM) : A Qualitative Exploration", International Conference Islam and Technology (ICONISTECH), 11-12 July 2019 in Bandung.

[24] Rosalina V., Munandar Ai., Hidayanto A.N., Santoso HB., (2020) Measuring Citizen Readiness To Adopt Electronic Citizen Relationship Management (e-CiRM) Using Technology Readiness Index (TRI), Journal Of Theoretical And Applied Information Technology (JATIT) Volume 98, E-ISSN 1817-3195 / ISSN 19928645). 